\title{
Challenges and opportunities for women entrepreneurs in Botswana: revisiting the role of entrepreneurship education
}

\author{
Norman Rudhumbu
}

Department of Curriculum Studies, Bindura University of Science Education, Bindura, Zimbabwe

EC (Elize) du Plessis

Department of Curriculum Studies, University of South Africa, Pretoria, South Africa, and

\section{Cosmas Maphosa}

Department of Curriculum Studies, University of Swaziland, Kwaluseni, Swaziland

Received 11 December 2019 Revised 3 April 2020 Accepted 8 April 2020

\begin{abstract}
Purpose - The purpose of this paper is to investigate challenges faced by and opportunities open to women entrepreneurs in Botswana and how entrepreneurship education can boost their knowledge and skills of doing business profitably and contribute to women empowerment.

Design/methodology/approach - In total, 400 women entrepreneurs of different ages, educational levels and from trades and different geographical locations were selected using a stratified random sampling procedure to participate in the study from ten towns and cities in the country. A structured questionnaire that used a five-point Likert scale was used for data collection. One-way ANOVA, regression analysis and descriptive statistics were used as tools for data analysis.

Findings - Findings showed that women entrepreneurs faced a complex web of challenges among which were access to finance, lack of training leading to lack of technical skills, lack of knowledge of sources of financing and technical support, high competition in the market, marginalisation of women and lack of knowledge of marketing strategies. The key findings were that while women entrepreneurs faced a number of challenges, the legal and regulatory environment in Botswana was highly conducive and supportive of women entrepreneurship and also that customised entrepreneurship education and training offered opportunities for women entrepreneurs to enhance their knowledge and technical skills.

Research limitations/implications - The study only used a quantitative approach to collect data. It could have perhaps been more enriching if a mixed-methods approach were used to help probe the participants more. The study also only used women entrepreneurs in cities and towns. Perhaps, it could have also got some women entrepreneurs from rural areas to hear what they say. These limitations will be addressed in future studies.

Practical implications - Practical implications of the study are that women entrepreneurs need more training in business entrepreneurship for them to gain more knowledge and skills; finance houses become more accommodating to women entrepreneurship they could help in the empowerment of these people as they
\end{abstract}

entrepreneurs in Botswana 
show potential in their businesses; and if more pro-women entrepreneurship policies are developed, they could enhance the activities of women entrepreneurs.

Social implications - Women can perform as much as men in business if given the necessary support.

Originality/value - This study contributes to the body of knowledge on women entrepreneurship as it helped expose challenges women entrepreneurs face as well as opportunities for them to take advantage of and improve their business operations.

Keywords Opportunities, Women empowerment, Entrepreneurship, Women entrepreneurs, Entrepreneurship education, Cultural barriers

Paper type Research paper

\section{Introduction}

Entrepreneurship in Botswana is viewed as very critical to economic growth and the eradication of poverty. As a result, there is much support given to women entrepreneurs in Botswana through various policy frameworks. A number of studies in Botswana have produced statistics that show how much of a footprint women entrepreneurs are making in the business market, despite a number of challenges they face. Separate studies by Kenya Wallstreet (2017), Vanek (2017) and Egbele and Deibele (2019) found that at a global level, Botswana ranked second to Uganda at $34.6 \%$ of the MasterCard Index in terms of women entrepreneurship activity rate and first in Africa at $66.6 \%$ in women advancement index and also first in Africa at $62.6 \%$ on providing supportive entrepreneurship conditions to women. Results of a study by the Sundaystandard (2012) and by the Central Statics Office (2009) in Okurut and Ama (2013) showed that $56.2 \%$ of women are employed in the formal economy, with $75 \%$ of these women more likely to start their own businesses. Such statistics help to show that there is certainly a lot of appetite by women to start and successfully run their own businesses if it were not for the challenges they face in the business environment. Literature also shows that despite a number of challenges which women entrepreneurs face, the legal and regulatory environment in Botswana is very conducive for starting up business ventures (Egg, 2015; Mansor and Mat, 2010).

Entrepreneurship has since the 1930s been considered a critical activity in developing and sustaining global economies. This is echoed by Ramadani et al. (2015) who posit that entrepreneurship is fast becoming an important driver of both economic growth and development in global economies. The critical role entrepreneurship plays in the growth and sustainability of global economies is well documented (Rao et al., 2012). Despite offering multiple and varied benefits to the entrepreneurship sector, women entrepreneurs continue to be viewed as an insignificant factor in entrepreneurship due to the dominance of male entrepreneurs (Mustapha and Subramaniam, 2016; Ramadani et al., 2015; Sowmya et al., 2010). Anwar and Rashid (2012) also recognise that women entrepreneurship is a critical empowerment and emancipation tool in terms of the improvement of the quality of life for women. This is supported by Bruin et al. (2007) who argue that there is no doubt that women entrepreneurship is growing, despite the fact that this growth is affected by a complex web of micro-level and macro-level variables. Women make up a big chunk of the global population yet their contribution to the global economy continues to be underestimated. For example, Bajpai (2014) shows that women make up to $50 \%$ of the global population and $40 \%$ of the global workforce; yet, they continue to be underrepresented in critical areas of the national economies. Other studies also confirm the above assertion through statistics that also show that women now constitute more than a third of all formal business in the global economy (Chinomona and Maziriri, 2015; Nxopo, 2014). This is why Tore (2020) asserted that womenowned and -led business ventures are strong catalysts for economic growth at a global level. 
As already alluded to above, in the context of Botswana, entrepreneurship and entrepreneurship education are considered very strategic economic activities that have attracted the attention of many of the nation's policymakers and educators (Munemo, 2012). Such recognition of the critical role entrepreneurship and entrepreneurship education play in the growth of the Botswana economy has led to the establishment of clear policy frameworks and programmes to catalyse and enhance the development of the spirit of entrepreneurship among citizens in general and women in particular. This recognition of the critical role of entrepreneurship and entrepreneurship education has also led to the development and implementation of entrepreneurship programmes in higher education institutions in Botswana (Assan, 2012). More specifically, the entrepreneurship policy framework in Botswana finds expression through the establishment of the following facilitating government agencies:

- Citizen Entrepreneurship Development Agency which is an umbrella body whose involvement in entrepreneurship transcends all sectors of the Botswana economy and whose specific mandate is to provide funding for entrepreneurship projects.

- The Local Enterprise Authority whose mandate is to provide advisory and mentoring services to both current and budding entrepreneurs.

- The Botswana Investment and Trade Centre whose sole mandate is to provide advice to entrepreneurs on issues related to exports and foreign direct investment.

- The National Development Bank whose mandate is to fund small and medium enterprises.

- The Botswana Development Corporation (BDC) whose mandate is to provide equity and partnerships in business, discounting and market research services (Themba and Josiah, 2015; Local Enterprise Agency, 2012; CEDA, 2012).

The above suite of entrepreneurship facilitating agencies is also complemented by other smaller government assisted institutions who assist in providing youths (who include young women) with entrepreneurial knowledge and skills and these institutions include the Youth Development Fund, Junior Achievement Botswana and the Botswana National Youth Council (Kenosi, 2011). The above agencies together with a conducive legal and regulatory framework in Botswana, act to provide good opportunities for women entrepreneurs to succeed in business ventures. Due to a conducive legal and regulatory framework, the economy of Botswana has performed very well over the years that the Global Competitive Report of 2017-2018 ranks Botswana at position 68 out of 314 countries (Schwab, 2017).

RQ1. What challenges do women entrepreneurs in Botswana face in their business ventures?

$R Q 2$. How can women entrepreneurs in Botswana deal with the challenges for the success of their business ventures?

RQ3. What opportunities currently exist in Botswana for women entrepreneurs to take advantage of and enhance their business ventures?

$R Q 4$. What is the role of business entrepreneurship education in enhancing the success of women in their business ventures?

Research hypotheses tested in the study are as follows:

H01. There is no significant relationship between access to finance and success of women entrepreneurship in Botswana. 
H02. There is no significant relationship between limited business networks and success of women entrepreneurship in Botswana.

H03. There is no significant relationship between entrepreneurship education and success of women entrepreneurship in Botswana.

H04. There is no significant relationship between entrepreneurship skills and success of women entrepreneurship in Botswana.

H05. There is no significant relationship between gender discrimination and success of women entrepreneurship in Botswana.

H06. There is no significant relationship between work and home responsibilities and success of women entrepreneurship in Botswana.

H07. There is no significant relationship between lack of family support and success of women entrepreneurship in Botswana.

\section{Literature review}

\subsection{The concepts of entrepreneurship and entrepreneur}

The definition and meaning of entrepreneurship has greatly evolved since the 1930s with two schools of thought dominating, namely, the innovation- and the resource-based schools of thought (Ahmad and Seymour, 2008). The innovation school of thought views entrepreneurship as an individual's ability to be innovative, to come up with a business idea and convert it into a business while the resource-based school of thought views entrepreneurship as an economic activity that relates to the strategic orientation, commitment to opportunity and resource deployment and control (Ahmad and Seymour, 2008; Casson, 2005). Chinomona et al. (2014) define entrepreneurship as the process of initiating, creating, building, expanding and sustaining a business venture by exploiting market opportunities. The word entrepreneurship however has its roots in the French word enterprendre which means to undertake (Anwar and Rashid, 2012) and as a result has had a bearing on our understanding of the word entrepreneur. Entrepreneurship education therefore is a form of education that enables women entrepreneurs to undertake their business ventures successfully by capacitating them with knowledge and technical skills required in business.

As a result of the historical meaning of entrepreneurship as an undertaking, an entrepreneur has been variously defined by a number of authorities. Mordi et al. (2010) define an entrepreneur as someone who undertakes a commercial enterprise and who is an organisational creator and innovator (a definition that merges both the innovation and resource-based views of entrepreneurship). Dzisi (2008) also views an entrepreneur as an innovator who creates and introduces something new into the economy, while Singh and Belwal (2008) also define an entrepreneur as someone who is motivated by an idea, personal goals and ambition to establish and run a business entity by bringing together financial capital, people, equipment and other facilities. According to Farr-Wharton and Brunetto (2007), an entrepreneur is a person who seeks out and identifies potentially profitable economic opportunities. The above definitions of an entrepreneur show clearly that our understanding of an entrepreneur is influenced by both the innovation- and resource-based schools of thoughts. A woman entrepreneur therefore is defined as a woman who initiates, creates and runs a business venture and is prepared to take risks (Manerkar, 2015). This is a woman who identifies potentially profitable economic opportunities, initiate a new business, 
actively participates in managing it and owns at least $50 \%$ of the business that should have been in operation for at least one year (Ahmad et al., 2011).

\subsection{Challenges women entrepreneurs face}

A number of studies show that the success of women entrepreneurs is curtailed by a complex blend of micro and macro variables in the economies which include lack of access to finance, lack of personal assets, stereotyping (marginalisation), fear of failure (psychological), lack of education and training, socio-cultural boundaries, limited networks, legal and regulatory requirements and poor marketing strategies (Jaya et al., 2015; Ahmed, 2016; Halkias et al., 2011; Nsengimana, 2017; Themba and Josiah, 2015; Anwar and Rashid, 2012; Itani et al., 2011; Bajpai, 2014; Kumbhar, 2013). Raising funds to initiate or run a business continues to be a challenge for women entrepreneurs owing to the fact that most lending institutions require collateral (Amalu and Okafor, 2010; Anwar and Rashid, 2012; Ali and Ali, 2013). Amalu and Okafor (2010) also argue that women entrepreneurs continue to be marginalised and not taken seriously in most sectors of the economy from customers to suppliers. This challenge is exacerbated by the fact that due to cultural issues, many women are not in possession of their personal assets to be able to use them as collateral to access funding (Zororo, 2011). Studies also who that the majority of women have inferior education that makes it difficult for them to have knowledge of sources of funding available and how to access such funding through sound business plans (Bullough and Abdelzaher, 2013; Halkias et al., 2011; Garba, 2013; Global Entrepreneurship Monitor, 2019; International Center for Research on Women, 2019). The above is also supported by Rao et al. (2012) who argue that as a result of negative perceptions of women entrepreneurs as lacking seriousness, women often get limited opportunities to access credit when compared to men; hence, they tend to resort to their meagre personal savings and family loans to finance their businesses, and this results in inadequate stocking and restocking of supplies.

Studies show that traditional belief systems such as the male - female role definition that suggest the subordination of women to men robes women of opportunities for leadership roles, self-confidence and self-expression all of which have negative ramifications to women when they want to stand on their own in businesses (Kapinga and Montero, 2017; Athanne, 2011: Mwobobia, 2012; Zororo, 2011; Mordi et al., 2010). As a result of the fact that cultural boundaries risk women in taking up decision-making roles in the families, women grow up with low self-esteem of themselves and with high levels of fear of failure (Mandipaka, 2014; Rao et al., 2012; Mwobobia, 2012; Athanne, 2011; Gichuki et al., 2014). Also, the importance of entrepreneurship education in capacitating women entrepreneurs cannot be overemphasised. It has been shown in separate studies by Amalu and Okafor (2010) and Magesa et al. (2013) that many women entrepreneurs lack entrepreneurial knowledge and technical skills due to the fact that they had limited opportunities for vocational and technical education and training in entrepreneurship for a sector which has always been believed to be for men. This has resulted in a void in women with regards to hands-on knowledge and skills to be able to run effectively their businesses.

The balance between work and home commitments is another challenge affecting women entrepreneurs. The success of women entrepreneurs is often compromised by their attempts to balance work and home commitments especially in terms of time allocation (Ihugba and Njoku, 2014; Behara and Niranjan, 2012; Jamali, 2009; Bruin et al., 2007; Rao et al., 2012). A study carried out by Starcher (1996) in Rao et al. (2012) showed that very few women can devote most of their time and energies to their businesses as compared to their families. This is also confirmed in a study by Wendy (2007) that showed that the workfamily interface demands associated with running a business and managing home 
responsibilities tend to seriously restrict the growth and potential of many women-owned business ventures. At the same time, lack of access to information communication technology that includes gadgets such as computers, internet, video conferencing and others to ensure smooth business communication with stakeholders and quicken business transaction, as well as enabling ease access, storage and retrieval of critical business data continues to be a challenge for women entrepreneurs (Ewere et al., 2015; Dutta and BibaoOsorio, 2012). Lack of both access to as well as knowledge of how to use these gadgets leaves women entrepreneurs with the challenges of keeping pace with the fast-changing business information thus affecting the viability of their ventures (Motilewa et al., 2015).

As a result of no training in entrepreneurship education, most of the women entrepreneurs face challenges with regards to how to effectively market their products and services (Kumari, 2012; Itani et al., 2011). Halkias et al. (2011) argue that level of entrepreneurship education has implications on how women take advantage of opportunities and effectively market their products and services. On the other hand, limited to lack of family support is another barrier to women success in their business ventures. Anwar and Rashid (2012) and also Maziku et al. (2014) argue that family support is critical for the success of business ventures of women entrepreneurs particularly with regards to the nurturing of entrepreneurial behaviour in women. Studies show that if family members are not supportive, this has a negative effect on the self-image, self-confidence and motivation to start and/or sustain a business venture (Itani et al., 2011; Halkias et al., 2011; Jamali, 2009; Majenga and Mashenene, 2015). The above is compounded by limited to no networks for the women entrepreneurs. Women entrepreneurs have limited networks due to the fact they always want to network with those they know and trust and would rather not explore new territories (Farr-Wharton and Brunetto, 2007; Robinson and Stubberud, 2009; Amalu and Okafor, 2010). Entrepreneurship education can therefore capacitate women entrepreneurs with a number of networking strategies they can use to improve the visibility of their nosiness to the market.

The legal and regulatory framework of a country can be either an enabler or barrier to women entrepreneurship. This is confirmed by Singh and Belwal (2008) and by Mansor and Mat (2010) who argued that a lack of government support through a conducive legal and regulatory framework can pose serious challenges to women entrepreneurs. Bharthvajan (2014) also argues that if the legal and regulatory requirements become too strict for small businesses, they can stifle the success of women entrepreneurs.

\section{Theoretical framework}

The study is informed by the theory of planned behaviour (TPB) developed by Ajzen (1985) which is an extension of the theory of reasoned action (Ajzen and Fishbein, 1980). The TPB is used to help us understand and predict behaviours. It posits that individuals make logical, reasoned decisions to engage in specific behaviours based on information available to them (Kan and Fabrigar, 2017; Long-Crowell, 2019; Ryan and Carr, 2010). It further asserts that why an individual perform a specific behaviour depends on the individual's intention to engage in it, that is, depends on the value the person places on the behaviour, the ease with which the behaviour can be performed, and the views of the significant others and the perception the performing the behaviour is within one's control (Ryan and Carr, 2010) as shown in Figure 1.

Intention is defined as a person's motivation to do something, that is, an individual's conscious plan or decision to expend effort to engage in a particular behaviour (Corner, 2001; Kan and Fabrigar, 2017). Based on Figure 1, and according to Norman and Conner (2017), it can be observed that behavioural intention is a function of three factors, that is attitudes (an 


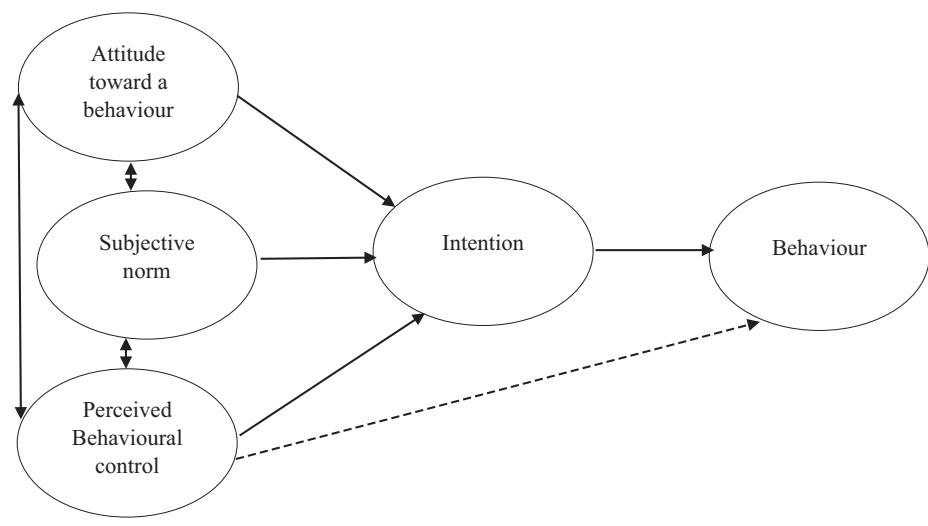

Source: Ajzen (1991, p. 182)
Women entrepreneurs in Botswana

Figure 1. Theory of planned behaviour

overall assessment of the value of a behaviour by the individual), subjective norms (a person's beliefs about whether the significant others that may include family, friends, partners, business associates and others, think that he/she should engage in the behaviour) and perceived behavioural control (a feeling that the performance of the behaviour is within one's control).

The above according to the TPB therefore means that people engage in a specific behaviour because of three things. First, they engage in a particular behaviour if they believe that the behaviour will lead to something or an outcome they value (attitude). In the context of the current study, women entrepreneurs engaged in the entrepreneurship ventures (specific behaviour) after observing that the business venture were going to be able to change and improve their lives. Second, people engage in specific behaviours if they believe that other people (significant others) whose views they cherish and value think they should engage in the behaviour (subjective norms). In the context of the current study, it is expected that the women entrepreneurs first sort the opinions of any or all of the following significant others: their family members, friends and business associates among others, before taking up the business ventures. Finally, individuals engage in a specific behaviour if they believe that they have maximum control over the behaviour (perceived behaviour control). In the context of the current study, women entrepreneurs who undertook to participate in their business ventures would have noted that they had necessary basic resources to start the businesses, there were opportunities for such businesses to be undertaken, they had the time, basic knowledge and skills, the regulatory environment was favourable, and they were going to have the cooperation of important stakeholders in the market if their business were to succeed.

\section{Materials and methods}

The study used a quantitative approach that used a structured questionnaire (developed by the researcher) for data collection. The questionnaire used a four-point Likert scale from Strongly Agree (4), Agree (3), Disagree (2) and Strongly Disagree (1). Based on this scale, a criterion mean was calculated as the average of the Likert scale points as follows $(4+3+2+1) / 4=10 / 4=2.5$. This result meant that any mean score below 2.5 signified negative result while any mean score from 2.5 and above signified confirmation result. Stratified random sampling strategy was used to select 400 women entrepreneurs from a 
population of 28,837 from across the major towns and villages of Botswana. The purpose of stratified sampling was to ensure that every population segment (by age, trade, education level, marital status and region) was proportionately represented in the study. The sample size of 400 respondents (using the sample size table of The Research Advisors, 2006) was arrived at using a sample size table at $95 \%$ level of confidence or $5 \%$ margin of error. The structured questionnaire was tested both for internal consistence reliability and content validity. Using the Cronbach's alpha reliability coefficient $\alpha$, the instrument achieved a reliability index of 0.83 and hence was deemed reliable enough to be used in the study. The instrument was also tested for content validity by being subjected to expert opinion and recommendations of the experts were incorporated into the instrument before it was administered.

In total, 400 questionnaires were thus administered to the respondents and 378 questionnaires were returned giving a return rate of $94.5 \%$. Data analysis was done using the Statistical Package for Social Sciences (SPSS) version 24. One-way ANOVA was used for testing hypotheses, while regression analysis was used to examine to what extent the identified challenges explained variation in the success of women entrepreneurs in Botswana. Before ANOVA test was conducted, a test of normality was done to check on whether to use a parametric or non-parametric measure to test hypothesis in the study. As data was found not to be normally distributed, a non-parametric measure was supposed to be used. However, the researcher used a parametric measure instead because when $n>30$, parametric measures which are more robust than non-parametric tests can be used to analyse non-normal data (Yu, 2008; Corder and Foreman, 2014; Vickers, 2005).

\title{
5. Findings
}

\subsection{Biographic characteristics of women entrepreneurs}

Results in Table 1 show that the majority of women (73\%) engaged in entrepreneurship are above the age of 30 years which indicates that most of these women are mature enough to be able to make, to some good extent critical decisions for their businesses. With regards to the

\begin{tabular}{llc}
\hline Demographic variable & Response categories & \% responses \\
\hline Age & $18-25$ years & 10.3 \\
& $26-30$ years & 16.7 \\
& $31-35$ years & 17.5 \\
& $36-40$ years & 24.8 \\
& $41^{+}$years & 30.7 \\
Business location & Urban & 30.5 \\
& Urban village & 38.5 \\
Education level & Rural village & 31 \\
& Up to primary school level & 22.2 \\
Experience in entrepreneurship & Secondary school level & 61.3 \\
& Tertiary education & 16.5 \\
& $0-5$ years & 21.8 \\
& $6-10$ years & 44.7 \\
Marital status & $11-15$ years & 18.5 \\
& $16-20$ years & 10.2 \\
& $21^{+}$years & 4.8 \\
& Yes & 40.5 \\
& No & 59.5 \\
\hline
\end{tabular}

Table 1.

Demographic variables $(N=378)$

\begin{abstract}
able tomake, to some good extent critical decisions for their businesses. With regards to the
\end{abstract}


location of their businesses, most businesses are located in urban cities and urban villages $(69 \%)$ which is as expected as many people would prefer to do businesses in an urban environment where utilities such as water, electricity and transportation and supplies are readily accessible. With regards to educational levels, the majority of women entrepreneurs $(61.3 \%)$ attained secondary education which means that most of them are able to read and write and perhaps comprehend basic business principles. Only $9.5 \%$ of the 378 women indicated that they never went to school. With regards to the level of experience in entrepreneurship, most women have ten and below years of experience which means for most of these women, entrepreneurship is still work in progress, and they still have a lot to learn in the sector. Most of the women entrepreneurs (59.5\%) are not married but have children they are raising, that is, they have families.

\subsection{Challenges women entrepreneurs face}

Table 2 shows that the major challenges women entrepreneurs in Botswana face are access to finance $(\mathrm{M}=3.35, \mathrm{SD}=1.218)$, gender discrimination $(\mathrm{M}=3.28, \mathrm{SD}=1.127)$, inferior education and training $(\mathrm{M}=3.12, \mathrm{SD}=1.265)$, socio-cultural boundaries $(\mathrm{M}=3.06$, $\mathrm{SD}=1.614)$, lack of access to information communication technology $(\mathrm{M}=3.05, \mathrm{SD}=1.113)$, balance between work and home responsibilities, $(\mathrm{M}=3.05, \mathrm{SD}=1.620)$ and limited business networks $(\mathrm{M}=3.01, \mathrm{SD}=1.109)$. Moderate challenges that women entrepreneurs face include lack of entrepreneurial skills $(\mathrm{M}=2.91, \mathrm{SD}=1.401)$, lack of family support and effective marketing strategies $(\mathrm{M}=2.61, \mathrm{SD}=1.5512)$. The legal and regulatory environment is perceived as not a challenge as it is viewed as conduces $(\mathrm{M}=1.04$, $\mathrm{SD}=1.007)$. From the above, it can therefore be concluded that the greatest of all challenges that women entrepreneurs face is access to finance while the least of worries they have is the legal and regulatory environment. The significance of challenges women entrepreneurs face with regards to the success of their business was further analysed using the one-way ANOVA test.

\subsection{Confirmatory factor analysis using partial least squares approach}

Table 3 is a representation of confirmatory factor analysis (CFA) results. Table 3 shows CFA results. CFA was conducted using the partial least squares (PLS) to determine the reliability as well as the convergent and discriminant validities of the scale items. Convergent validity is "when each scale item measurement correlates strongly with its assumed theoretical construct while discriminant validity is when each scale item measurement correlates weakly with other constructs except for the one to which it is

\begin{tabular}{|c|c|c|c|c|}
\hline Challenge faced by women entrepreneurs & $N$ & Mean (M) & Std Dev (SD) & \\
\hline Lack of access to finance & 378 & 3.35 & 1.218 & \\
\hline Gender bias/discrimination & 378 & 3.28 & 1.127 & \\
\hline Inferior education and training & 378 & 3.12 & 1.265 & \\
\hline Socio-cultural boundaries & 378 & 3.06 & 1.614 & \\
\hline Access to information communication technology & 378 & 3.05 & 1.113 & \\
\hline Balance between work and home responsibilities & 378 & 3.05 & 1.620 & \\
\hline Limited business networks & 378 & 3.01 & 1.109 & \\
\hline Lack of entrepreneurial skills & 378 & 2.91 & 1.401 & Table 2. \\
\hline Lack of family support & 378 & 2.88 & 1.440 & Challenges women \\
\hline Marketing strategies & 378 & 2.61 & 1.512 & entrepreneurs face \\
\hline Legal and regulatory framework & 378 & 1.04 & 1.007 & $($ criterion mean $=2.50)$ \\
\hline
\end{tabular}


theoretically associated" (Gefen and Straub, 2005, p. 13). Results in Table 3 hence show that all constructs meet the requirements of reliability, convergent and discriminant validity. Reliability was measured through internal consistency reliability using the Cronbach's alpha index. Results of the study showed an alpha index of 0.833 which is above the minimum threshold internal consistency reliability alpha value of 0.700 as recommended by Pontes and Griffiths (2015) and Tavakol and Dennick (2011), thus showing that the scale was reliable enough for the study. The average variance extracted (AVE) which measures the variance captured by a latent construct (the explained variance) is greater than the interconstruct correlations as explained by Valentinin and Damasio (2016). Table 3 also shows that composite reliability coefficients of all constructs and the AVE are adequate as they range from 0.805 to 0.951 and from 0.641 to 0.750 , respectively.

\subsection{Hypotheses testing}

With respect to H01, Table 4 shows that a lack of access to finance had a significant effect on the success of women entrepreneurs in Botswana $(\mathrm{F}(9,368)=31.368, p<0.005)$. This means women entrepreneurs have to struggle to raise capital from their own initiatives as official sources of finance such as banks and others do not seem open to lending money to women. This confirmed earlier results in Table 2 that showed that with regards to access to finance, $\mathrm{M}=3.35, \mathrm{SD}=1.218$ which showed that lack of access to finance had a very high negative effect on women entrepreneurs' success in their business ventures in Botswana.

With respect to HO2, the results in Table 5 show that a lack of adequate business networks had a significant effect on the success of businesses of women entrepreneurs $(F(9,368)=33.774$,

Table 3.

Confirmatory factor analysis

\begin{tabular}{lccc}
\hline Construct & Items & Composite reliability & AVE \\
\hline Access to finance & 3 & 0.825 & 0.641 \\
Business networks & 3 & 0.917 & 0.725 \\
Entrepreneurship education & 4 & 0.805 & 0.742 \\
Entrepreneurship skills & 5 & 0.833 & 0.740 \\
Gender discrimination & 4 & 0.951 & 0.750 \\
Work and home responsibilities & 4 & 0.826 & 0.731 \\
Family support & 4 & 0.749 & 0.661 \\
\hline
\end{tabular}

\begin{tabular}{lcrccr}
\hline Source & Sum of squares & df & Mean of squares & $F$ & Sig. \\
\hline Between groups & 606.679 & 9 & 67.442 & 31.368 & 0.003 \\
Within groups & 791.247 & 368 & 2.150 & & \\
Total & 1397.926 & 377 & & &
\end{tabular}

Table 4. ANOVA for access to finance

Note: Significant $(p<0.05)$

\begin{tabular}{lcrcrr}
\hline Source & Sum of squares & df & Mean of squares & $F$ & Sig. \\
\hline Between groups & 316.432 & 9 & 35.159 & 33.774 & 0.001 \\
Within groups & 382.902 & 368 & 1.041 & & \\
Total & 699.334 & 377 & & & \\
\multicolumn{2}{l}{ Note: Significant $(\phi<0.05)$} & & & & \\
\hline
\end{tabular}


$p<0.05$ ). This confirms earlier descriptive statistics results in Table 2 that showed that a lack of access to business networks had a negative effect on women entrepreneurs' success ( $M=3.01$, $\mathrm{SD}=1.109)$.

With respect to $H 03$, the results in Table 6 show that entrepreneurship education has an impact on how women engage in entrepreneurship activities $(\mathrm{F}(9,368)=10.666, p<0.05)$. This shows that if women participate in entrepreneurship education and training, they get empowered with both knowledge and technical skills to be able to develop and manage their businesses more effectively. These results also confirm earlier results in Table 2 that indicated that entrepreneurship education and training is critical to the success $(\mathrm{M}=3.12$, $\mathrm{SD}=1.265$ ) of women entrepreneurs in their business ventures.

With respect to HO4, the results in Table 7 show that a lack of entrepreneurial skills amongst women entrepreneurs in Botswana was negatively affecting their success in their ventures $\mathrm{F}(9,368)=10.532, p<0.05$. These results further highlight the importance of entrepreneurship education and training as earlier highlighted and also help to confirm results in Table 2 with regards to the fact that to a large extent, if women entrepreneurs fail to receive entrepreneurship education and training, they will continue failing $(\mathrm{M}=2.91$, $\mathrm{SD}=1.401)$ in their business ventures.

With respect to $\mathrm{HO5}$, the results in Table 8 show that gender discrimination has a negative effect on the success of women entrepreneurs in Botswana $(\mathrm{F}(9,351)=11.068, p<0.05)$. Women entrepreneurs continue to suffer from male domination syndrome and the biases of society as shown in earlier results in Table 2 that showed that gender bias has a very high negative influence on the success of women entrepreneurs $(\mathrm{M}=3.28, \mathrm{SD}=1.122)$.

\begin{tabular}{lcrccr}
\hline Source & Sum of squares & df & Mean of squares & $F$ & Sig. \\
\hline Between groups & 201.592 & 9 & 22.399 & 10.666 & 0.000 \\
Within groups & 772.327 & 368 & 2.1 & & \\
Total & 973.919 & 377 & & &
\end{tabular}

Note: Significant $(p<0.05)$

Table 6. ANOVA for

Entrepreneurship education and training

\begin{tabular}{lcrccr}
\hline Source & Sum of squares & df & Mean of squares & $F$ & Sig. \\
\hline Between groups & 191.009 & 9 & 21.223 & 10.532 & 0.004 \\
Within groups & 741.558 & 368 & 2.015 & & \\
Total & 932.567 & 377 & & &
\end{tabular}

Note: Significant $(p<0.05)$

Table 7. ANOVA for Entrepreneurial skills

\begin{tabular}{lcrccr}
\hline Source & Sum of squares & \multicolumn{1}{c}{ df } & Mean of squares & $F$ & Sig. \\
\hline Between groups & 569.0 .327 & 9 & 63.259 & 19.298 & 0.000 \\
Within groups & 1205.419 & 368 & 3.278 & & \\
Total & 1774.746 & 377 & & &
\end{tabular}

Note: Significant $(p<0.05)$

Table 8.

ANOVA on gender discrimination 
With respect to HO6, Table 9 showed that a lack of a good balance between work and home responsibilities has a significant negative effect on the success of women entrepreneurs $(\mathrm{F}(9,368)=18.278, p<0.05)$. These results therefore further show that family responsibilities and chores continue to take the greater part of women entrepreneurs' business time thus affecting business performance as confirmed in earlier results in Table 2 that showed that most women entrepreneurs fail to strike a balance between their family life and business commitments $(\mathrm{M}=3.05, \mathrm{SD}=1.620)$ this negatively affected their business ventures when compared to their male counterparts.

With respect to $H 07$, the results in Table 10 showed that a lack of family support did not have a significant effect on the success of women entrepreneurs $(F(9,368)=2.089, p>0.05)$. These results therefore show that women are not significantly affected by a lack of family support in their businesses and would do the work on their own to their best abilities. These results also confirm earlier results in Table 2 that showed that a lack of family support $(\mathrm{M}=2.88, \mathrm{SD}=1.440)$ did not negatively affect the success of women entrepreneurs.

The regression model in Table 11 demonstrated the extent to which challenges facing women entrepreneurs explained the low levels of success of women in their business ventures.

Based on results in Table 11, the adjusted $R^{2}$ which has a greater explanatory power than $R^{2}$, is equal to 0.5269 . The above results therefore show that the low level of success $(52.69 \%)$ of women entrepreneurship could be explained by the presents of the following challenges: lack of access to finance, ineffective marketing strategies, lack of family support, interface between home and work life, lack of access to information communication technology, inferior education and training, lack of entrepreneurial skills, limited business networks, gender discrimination and socio-cultural boundaries. The remaining $47.31 \%$ could be explained by other extraneous factors which were not part of this study.

Table 9. ANOVA on balancing between work and home responsibilities

\begin{tabular}{|c|c|c|c|c|c|}
\hline Source & Sum of squares & $\mathrm{df}$ & Mean of squares & $F$ & Sig. \\
\hline Between groups & 295.281 & 9 & 32.809 & 18.278 & 0.000 \\
\hline Within groups & 660.418 & 368 & 1.795 & & \\
\hline Total & 913.894 & 377 & & & \\
\hline \multicolumn{6}{|c|}{ Note: Significant $(\not<0.05)$} \\
\hline
\end{tabular}

\section{Table 10.}

ANOVA on lack of family support

\begin{tabular}{lcrccr}
\hline Source & Sum of squares & df & Mean of squares & $F$ & Sig \\
\hline Between groups & 15.273 & 9 & 1.697 & 2.089 & 0.097 \\
Within groups & 299.001 & 368 & 0.8125 & & \\
Total & 314.274 & 377 & & &
\end{tabular}

Note: Significant $(p<0.05)$ 


\section{Discussion of results}

Results showed that the women entrepreneurship in Botswana were affected by a multiplicity of challenges chief of which were lack of access to finance, gender discrimination, socio-cultural boundaries, inferior education and training as balancing between work and family responsibilities. For the women entrepreneurs to be able to effectively be engaged in their business ventures and in line with the TPB as articulated by Ajzen (1985), they need all critical variables to be available. Such variables include resources, time, support, business knowledge and skills among others. With these available, women entrepreneurs, in line with the TPB, develop the right attitudes, feel that they are getting the right amount of support and will also feel that they have control over their businesses to be able to succeed. The challenges women entrepreneurs face therefore need to be addressed as a matter of urgency. A lack of such crucial requirements such as finance and training were particularly worth noting because without a strong financial base, it is very difficult for women to succeed in the ventures. Finance is particularly important in helping women establish requisite infrastructure for their businesses as well as in ensuring effective restocking of the needed resources. With regards to training, knowledge of areas such as business growth strategies as well as marketing strategies, among others, the study showed that exposing women entrepreneurs to entrepreneurship education and training will help capacitate them with the necessary knowledge and skills to be able to successfully and profitably run their business. Without business training therefore, women will certainly find it difficult to succeed in their businesses in this knowledge economy. The issue of segregating women especially in the economic field continues to be an issue of concern according to results of this study. Segregation of women especially due to socio-cultural connotations and boundaries means that women will not be adequately exposed to business opportunities and resources, thus affecting the growth of their businesses. Such segregation where women are regarded as inferior tends to reduce confidence in women, thus potentially affecting their enthusiasm and confidence with regards to the manner they approach their businesses.

A number of studies have highlighted the effect of these challenges on the success of women entrepreneurs (Halkias et al., 2011; Themba and Josiah, 2015; Anwar and Rashid, 2012; Itani et al., 2011; Bajpai, 2014; Global Entrepreneurship Monitor, 2019; Kumbhar, 2013). In their separate studies, Anwar and Rashid (2012) and also Amalu and Okafor (2010) found that women fail to access finance for their projects because of failure to provide collateral owing to the fact that most of them do not have personal assets. Rao et al. (2012) also alluded to the fact that one of the major reasons why financial institutions do not advance money to women entrepreneurs was the negative perception that women are not serious at all and may wastes scarce financial resources. In their study on challenges affecting women entrepreneurs, Halkias et al. (2011) found that inferior education and training that characterise women entrepreneurs negatively affected their businesses especially with regards to coming up with business plans and strategies that can be used to access finance from financial institutions and effectively market their products.

Results of the study further showed that challenges facing women entrepreneurs were also compounded by socio-cultural boundaries where women are treated as second rate citizens subordinate to their male counterparts hence not able to either acquire personal assets or assume leadership roles in families. This according to a number of studies, stifles decision-making processes of women and also reduces their self-esteem and self-confidence, thus affecting how they run their businesses (Athanne, 2011; International Center for Research on Women, 2019; Mwobobia, 2012; Nsengimana, 2017; Zororo, 2011; Mordi et al., 2010). Amalu and Okafor (2010) in their study also found that due to their limited 
opportunities to attend vocational education and training such as entrepreneurship training, a sector ordinarily reserved for men, women entrepreneurs lacked entrepreneurship skills, hence the problems they face when running their businesses.

It also emerged from the study and confirmed by earlier studies that failure to balance home and work responsibilities negatively affects most women entrepreneurs. For example, an earlier study by Starcher (1996) in Rao et al. (2012) found that very few women can devote most of their time and energies to their businesses as compared to their families. In the same study, it was also found that access to information technology was affecting women entrepreneurship, thus confirming results of another study by Motilewa et al. (2015) which found that a lack of access to information communication technology left women entrepreneurs with the problem of failing to keep pace with the fast-changing business information systems thus affecting the viability of their ventures.

\section{Conclusions and recommendations}

Based on the results of the study, there a number of conclusions were made. First, women entrepreneurs face a complex blend of challenges in Botswana with limited access to finance being the greatest challenge women entrepreneurs face, despite the availability of multiple sources of finance from banks to government agencies such as CEDA (2012). Second, entrepreneurship education and training can help capacitate women entrepreneurs with knowledge and technical skills on how to make business plans and access money from financial institutions as this is lacking in these women. Third, despite the many challenges women entrepreneurs were facing in the Botswana market, opportunities for growth and expansion of the entrepreneurship sector are very high in Botswana owing to a conducive legal and regulatory environment set up by the Botswana Government which women can take advantage of. It is also concluded that women entrepreneurs are not affected by lack of business support in their business and thrive without this support.

The following recommendations were made based on the results of the study. First, women entrepreneurs require training in entrepreneurship to be able to develop and enhance their business skills and knowledge. This will help them in the areas of coming up with business plans and marketing strategies for their business. Second, all governance agencies mandated with the development of entrepreneurship in the country need to come up with programmes to empower women entrepreneurs with basic knowledge through a customised entrepreneurship education and training programme especially on how to identify sources of finance and how to access that finance as this is part of these institutions' mandates.

\section{References}

Ahmad, N. and Seymour, R.G. (2008), "Defining entrepreneurial activity", Definitions Supporting Frameworks for Data Collection, OECD Statistics Working Papers, Paris.

Ahmad, S.Z., Xavier, S.R., Perumel, S., Nor, M.L. and Mohan, C.J. (2011), "The transition from corporate careers to business ownership: the case for women entrepreneurs in Malaysia", International Journal of Business Administration, Vol. 2 No. 3, pp. 23-29.

Ahmed, M.S. (2016), "Challenges facing women entrepreneurship among the Swahili community inMvita constituency in Mombasa county", Coastal Kenya. Masters Dissertation submitted to the University of Nairobi.

Ajzen, I. (1985), "From intentions to actions: a theory of planned behavior", in Kuhl, J. and Beckman, J. (Eds), Action-Control: From Cognition to Behavior, Springer, Heidelberg, pp. 11-39.

Ajzen, I. (1991), "The theory of planned behaviour", Organizational Behavior and Human Decision Processes, Vol. 50 No. 2, pp. 179-211. 
Ajzen, I. and Fishbein, M. (1980), Understanding Attitudes and Predicting Social Behaviour, Prentice Hall, Englewood Cliffs, NJ.

Ali, A.H. and Ali, A.Y. (2013), "Challenges and constraints faced by Somali women entrepreneurs in Benadir region”, Interdisciplinary Journal of Contemp Res Bus, Vol. 5 No. 2, pp. 436-411.

Amalu, R. and Okafor, C. (2010), "Entrepreneurial motivations as determinants of women entrepreneurship challenges", Economic Sciences Series, No. 2, pp. 67-77.

Anwar, M.U. and Rashid, A.G. (2012), "Female entrepreneurs - a review of the literature and proposed conceptual framework", available at: www.umt.edu.pk/icobm2012/pdf/2C- (accessed 19 June 2017).

Assan, T.B. (2012), "Youth entrepreneurial skills training as a source of employment in the NorthEastern part of Botswana", The Anthropologist, Vol. 14 No. 6, pp. 517-526.

Athanne, N. (2011), "Entrepreneurship in Kenya", Nairobi, available at: iiste.org/Journals/index.php/ EJBM/article/download/33856/34806 (accessed 11 May 2017).

Bajpai, G.C. (2014), "African women entrepreneur: problems, challenges and future opportunities", International Journal of Managerial Studies and Research (IJMSR), Vol. 2 No. 5, pp. 17-22.

Behara, S.R. and Niranjan, K. (2012), "Rural women entrepreneurship in India", IJCEM International Journal of Computational Engineering and Management, Vol. 15 No. 6, pp. 6-15.

Bharthvajan, R. (2014), "Women entrepreneurs and problems of women entrepreneurs", International Journal of Innovative Research in Science, Engineering and Technology, Vol. 3 No. 9, pp. 16105-16110.

Bruin, A., Brush, C. and Welter, F. (2007), "Advancing a framework for coherent research on women's entrepreneurship", Entrepreneurship Theory and Practice, Vol. 31 No. 3, pp. 323-339.

Bullough, A. and Abdelzaher, D. (2013), "Global research on women's entrepreneurship: an overview of available data sources and limitations", Business and Management Research, Vol. 2 No. 3, pp. 42-59.

Casson, M. (2005), "Entrepreneurship and the theory of the firm", Journal of Economic Behavior and Organization, Vol. 58 No. 2, pp. 327-348.

CEDA (2012), Citizen Entrepreneurial Development Agency Annul Report, March 31. Central Statistics Office (2009). 2007 Informal Sector Survey Report. Gaborone.

Central Statistics Office [CSO] (2009), 2007 Informal Sector Survey Report, Gaborone, available at: www.issuelab.org/resource/women-and-youth-entrepreneurship-in-botswana.html (accessed 13 February 2018).

Chinomona, E. and Maziriri, E. (2015), "Women in action: challenges facing women entrepreneurs in the Gauteng province of South Africa", International Business and Economics Research Journal, Vol. 14 No. 6, pp. 835-850.

Chinomona, E., Maziriri, E. and Moloi, K.C. (2014), "Corporate entrepreneurship with innovation in mind in one university of technology in South Africa", Mediterranean Journal of Social Sciences, Vol. 5 No. 23, pp. 20-29.

Corder, G.W. and Foreman, D.I. (2014), Nonparametric Statistics: A Step-by-Step Approach, John Wiley, London.

Corner, M. (2001), "Heath behaviours", International Encyclopedia of the Social \&Behavioral Sciences, Center for Advanced Study in Behavioural Sciences, Stanford, CA.

Dutta, S. and Bibao-Osorio, B. (2012), "The global information technology report 2012: living in a hyper connected world. World economic forum", available at: www3.weforum.org/docs/ Global_IT_Report_2012.pdf (accessed 27 July 2017).

Dzisi, S. (2008), "Entrepreneurial activities of indigenous African women: a case of Ghana”, Journal of Enterprising Communities: People and Places in the Global Economy, Vol. 2 No. 3, pp. 254-264. 
Egbele, T. and Deibele, B. (2019), "Uganda, Ghana and Botswana have highest percentage of women business owners in the world, finds Mastercard index", available at: https://newsroom. mastercard.com/mea/press-releases/ (accessed 15 March 2020).

Egg, R. (2015), "Women empowerment through business member organization series”, available at: www.itcilo.org/.../Women\%20Empowerment_Country\%20fact-sheet_South\%20Afric... (accessed 13 August 2017).

Ewere, A.D., Adu, E.O. and Ibrahim, S.I. (2015), "Strategies adopted by women entrepreneurs to ensure small business success in the Nkonkobe municipality, Eastern Cape”, Journal of Economics, Vol. 6 No. 1, pp. 1-7.

Farr-Wharton, R. and Brunetto, Y. (2007), "Women entrepreneurs, opportunity recognition and government-sponsored business networks: a social capital perspective", Women in Management Review, Vol. 22 No. 3, pp. 187-207.

Garba, B.A. (2013), "The case for women entrepreneurs and national security in Nigeria. 2nd national conference on national security for Nigeria's development, AbubakarTatari ali polytechnic Bauchi”, available at: eprints.uthm.edu.my/5776/1/8.Suleiman_Mohammeds_Lame.pdf (accessed 21 May 2017).

Gefen, D. and Straub, D. (2005), "A practical guide to factorial validity using PLS-Graph: tutorial and annotated example", Communications of the Association for Information Systems, Vol. 16, pp. 1-10.

Gichuki, C.N., Mulu-Mutuki, M. and Kinuthia, L.N. (2014), "Performance of women owned entreprises accessing credit from village credit and savings associations in Kenya", Journal of Global Entrepreneurship Research, Vol. 4 No. 1, p. 16.

Global Entrepreneurship Monitor (2019), Global Entrepreneurship Monitor: 2018-2019 Global Report, available at: https://gemconsortium.org/report/50213 (accessed 4 March 2020).

Halkias, D., Nwajiuba, C., Harkiolakis, N. and Caracatsanis, S.M. (2011), "Challenges facing women entrepreneurs in Nigeria", Management Research Review, Vol. 34 No. 2, pp. 1-10.

Ihugba, O.A. and Njoku, A.C. (2014), "Theoretical analysis of entrepreneurship challenges and prospects in Nigeria", International Letters of Social and Humanistic Sciences, Vol. 16, pp. 21-34.

International Center for Research on Women (2019), "Women entrepreneurs need more than capital what do women's businesses really need to grow and thrive?", available at: www.icrw.org (accessed 11 March 2020).

Itani, H., Sidani, Y.M. and Baalbaki, I. (2011), “United Arab Emirates female entrepreneurs: motivations and frustrations. Equality diversity and inclusion”, Equality, Diversity and Inclusion: An International Journal, Vol. 30 No. 5, pp. 409-424.

Jamali, D. (2009), "Constraints and opportunities facing women entrepreneurs in developing countries: a relational perspective", Gender in Management: An International Journal, Vol. 24 No. 4, pp. $232-251$.

Jaya, C., Gaurav, S. and Bajpai, G. (2015), "The challenges faced by women entrepreneurs in business expansion. A case study of women members of handicraft cooperatives in Nyarugenge district", Africalics 2nd international conference: Kigali Affiliation, University of Rwanda, Rwanda, November, 2015.

Kan, M.P.H. and Fabrigar, L.R. (2017), "Theory of planned behaviuor", available at: https://link. springer.com/referenceworkentry/10.1007\%2F978-3-319-28099-8_1191-1 (accessed 25 March 2020).

Kapinga, A.F. and Montero, C.S. (2017), "Exploring the socio-cultural challenges of food processing women entrepreneurs in Iringa, TANZANIA and strategies used to tackle them", Journal of Global Entrepreneurship Research, Vol. 7 No. 1, pp. 1-10.

Kenosi, P.Q. (2011), "Entrepreneurship through the junior achievement Botswana programme: realities and perceptions", Unpublished Doctoral dissertation. 
Kenya Wallstreet (2017), Report: Uganda has the most entrepreneurial women in the world, available at: http://keyawallstreet.com/author/easuma/ (accessed 21 February 2020).

Kumari, S. (2012), "Challenges and opportunities for women entrepreneurship in India under globalisation”, IOSR Journal of Business and Management (IOSR-JBM), Vol. 5 No. 2, pp. 29-35.

Kumbhar, V. (2013), "Some critical issues of women entrepreneurship in rural India”, European Academic Research, Vol. I No. 2, pp. 185-192.

Local Enterprise Agency (2012), “Women entrepreneurship”, available at: www.lea.co.bw/ (accessed 18 March 2018).

Long-Crowell, E. (2019), “Theory of planned behaviour”, available at: https://study.com/academy/lesson/ theory-of-planned-behavior-definition-examples-usefulness.html (accessed 17 March 2020).

Magesa, C., Shimba, C. and Magombola, D. (2013), "Investigating impediments towards access to financial services by women entrepreneurs: a case of Arumeru district", Development Country Studies, Vol. 3 No. 11, pp. 105-115.

Majenga, A. and Mashenene, R.G. (2015), "Socio-cultural factors and financial performance among women small and medium enterprises in Tanzania", European Journal of Business Management, Vol. 6 No. 32, pp. 153-163.

Mandipaka, F. (2014), "Overview of women entrepreneurs in South Africa”, Mediterranean Journal of Social Sciences, Vol. 5 No. 9, pp. 127-130.

Manerkar, G.A. (2015), “Women entrepreneurs in Goa: issues and challenges”, Indian Streams Research Journal, Vol. 4 No. 12, pp. 1-8.

Mansor, N. and Mat, A.C. (2010), "The significance of psychology and environment dimensions for Malaysian Muslim women entrepreneurships venturing", International Journal of Human Sciences, Vol. 7 No. 1, pp. 253-269.

Maziku, P., Majenga, A. and Mashenene, G.R. (2014), "The effect of socio-cultural factors on the performance of women small and medium enterprises in Tanzania", Journal of Economic Sustainable Development, Vol. 5 No. 21, pp. 51-62.

Mordi, C., Simpson, R., Singh, S. and Okafor, C. (2010), "The role of cultural values in understanding the challenges faced by female entrepreneurs in Nigeria", Gender in Management: An International Journal, Vol. 25 No. 1, pp. 5-21.

Motilewa, B.D., Onakoya, O.A. and Oke, A.O. (2015), "ICT and gender specific challenges faced by female entrepreneurs in Nigeria", International Journal of Business and Social Science, Vol. 6 No. 3, pp. 97-105.

Munemo, J. (2012), "Entrepreneurship in developing countries: is Africa different?", Journal of Developmental Entrepreneurship, Vol. 17 No. 1, pp. 1-12.

Mustapha, M. and Subramaniam, P. (2016), "Challenges and success factors of female entrepreneurs: evidence from a developing country", International Review of Management and Marketing, Vol. 6 No. 4, pp. 224-231.

Mwobobia, F.M. (2012), "The challenges facing small- scale women entrepreneurs: a case of Kenya", International Journal of Business Administration, Vol. 3 No. 2, pp. 1-10.

Norman, P. and Conner, M. (2017), "Health behaviour", available at: www.sciencedirect.com/topics/ neuroscience/theory-of-planned-behavior (accessed 13 March 2020).

Nsengimana, S. (2017), Challenges to Women Entrepreneurship in Kigali, Master of Technology: Business Administration in Entrepreneurship in the Faculty of Business and Management Sciences at the Cape Peninsula University of Technology, Rwanda.

Nxopo, Z. (2014), "The role of government in empowering female entrepreneurs in the Western Cape, South Africa", Master of Technology: Business Administration (Entrepreneurship), Cape Peninsula University of technology. Cape Town. 
Okurut, F.N. and Ama, N.O. (2013), "Assessing factors that affect women and youth MicroEntrepreneurs in Botswana", International Journal of Academic Research in Economics and Management Sciences, Vol. 2 No. 1, pp. 306-332.

Pontes, H.M. and Griffiths, M.D. (2015), "Measuring DSM-5 internet gaming disorder: development and validation of a short psychometric scale", Computers in Human Behavior, Vol. 45, pp. 137-143.

Ramadani, V., Hisrich, R.D. and Gerguri, S. (2015), "Female entrepreneurs in transition economies: insights from Albania", World Review of Entrepreneurship, Management and Sustainable Development, Vol. 11 No. 4, pp. 391-413.

Rao, V., Venakatachalam, A. and Joshi, H.G. (2012), "Challenges faced by women entrepreneurs running micro, small and medium scale fashion and apparel business: a study on fashion and apparel enterprises in coastal Karnataka", International Conference on Trade, Tourism and Management (ICTTM'2012) December 21-22, Bangkok (Thailand).

Robinson, S. and Stubberud, H.A. (2009), "Sources of advice in entrepreneurship: gender differences in business owners social networks", International Journal of Entrepreneurship, Vol. 13, pp. 83-101.

Ryan, S. and Carr, A. (2010), "Applying the biopsychosocial model to the management of rheumatic disease", available at: www.sciencedirect.com/topics/neuroscience/theory-of-planned-behavior (accessed 5 March 2020).

Schwab, K. (2017), The Global Competitiveness Report 2017-2018, available at: www3.weforum.org, (accessed 17 January 2018).

Singh, G. and Belwal, R. (2008), "Entrepreneurship and SMEs in Ethiopia: evaluating the role, prospects and problems faced by women in this emergent sector", Gender in Management: An International Journal, Vol. 23 No. 2, pp. 120-136.

Sowmya, D.V., Majumdar, S. and Gallant, M. (2010), "Relevance of education for potential entrepreneurs: an international investigation”, Journal of Small Business and Enterprise Development, Vol. 17 No. 4, pp. 626-640.

Starcher, D.C. (1996), "Women entrepreneurs: catalysts for transformation”, available at: www.ebbf. org/woman.htm (accessed 23 May 2017).

Sundaystandard (2012), "Women in businesses in Botswana", available at: www.sundaystandard.info/ women-businesses-botswana (accessed 25 September 2017).

Tavakol, M. and Dennick, R. (2011), “Are Asian international medical students just rote learners?”, Advances in Health Sciences Education, Vol. 15 No. 3, pp. 369-377.

The Research Advisors (2006), The Morgan's Table for Sample Size, available at: www. shodhgangashodhganga.inflibnet.ac.in (accessed 13 February 2018).

Themba, J. and Josiah, J. (2015), "Entrepreneurship development in Botswana lessons for other developing countries", Botswana Journal of Business, Vol. 8 No. 1, pp. 12-35.

Tore, O. (2020), "Top 10 countries for women entrepreneurs", available at: http://ftnews.com/newsfrom-turkey/ (accessed 2 April 2020).

Valentinin, F. and Damasio, B.F. (2016), "ArtigosOriginaisVariânciaMédiaExtraída e ConfiabilidadeComposta: indicadores de precisão", Psicologia: Teoria e Pesquisa, Vol. 32 No. 2, pp. 1-7.

Vanek, M. (2017), "This African country ranks first in the world for women business owners", available at: www.cnbcafrica.com/author/monique/ (accessed 5 March 2020).

Vickers, A. (2005), "Parametric versus non-parametric statistics in the analysis of randomized trials with non-normally distributed data”, BMC Medical Research Methodology, Vol. 5 No. 1, pp. 1-12.

Wendy, M. (2007), "Theorising a framework of factors influencing performance of women entrepreneurs in Malaysia”, Journal of Asia Entrepreneurship and Sustainability, Vol. III No. 2, pp. 36-41. 
Yu, C. (2008), "Parametric tests: restrictions of parametric tests", available at: http://creative-wisdom. com (accessed 5 March 2015).

Zororo, M. (2011), "Characteristics and motivation in female entrepreneurship. Case of Botswana", University of Botswana Journal, Vol. 26 No. 3, pp. 91-100.

Women entrepreneurs in Botswana

\begin{abstract}
About the authors
Prof Norman Rudhumbu has 30 years of experience in teaching, management, research and community service in schools, colleges and universities. Acted in the capacities of School Head, Principal Lecturer, HOD, Assistant Dean and Dean. He also hholds the following academic and professional qualifications: PhD, DEd, MPhil, MSc, MBA, MEd, BED, Dip Ed. He has published 35 papers in peer-reviewed journals and presented in 7 regional and international conferences. He is an author of one business management textbook and nine Mathematics textbooks, a number of which have been prescribed for use in Botswana schools. His three main research interests are critical studies in curriculum and pedagogy; learning, schools and innovations; and teaching and teacher education. Norman Rudhumbu is the corresponding author and can be contacted at: nrudhumbu@ buse.ac.zw

EC (Elize) du Plessis holds a DEd degree and has 30 years' experience in distance teaching. She is a full Professor in the Department of Curriculum and Instructional studies at the University of South Africa (Unisa) and is also involved in curriculum development in its School of Teacher Education. Her field of specialisation is curriculum development, teaching and learning and distance education. She is currently the programme coordinator of the Post Graduate Certificate in Education programme (Senior and FET phase). She is an experienced developer of course material for student teachers. She has made contributions to several books and a variety of journals, and presented papers at both national and international conferences. Elize is also a national and international reviewer for several academic journals and acts as supervisor for MEd and DEd students.

Cosmas Maphosa holds a PhD degree and has 32 years' teaching experience in schools and universities. He is a full Professor and currently a Director of Research at the University of Eswathini. His fields of specialisation is curriculum studies and research. He is an experienced researcher who has published widely in a number of journals, and presented papers at both national and international conferences. Cosmas is also a national and international reviewer for several academic journals and acts as supervisor for masters and $\mathrm{PhD}$ students.
\end{abstract}

For instructions on how to order reprints of this article, please visit our website: www.emeraldgrouppublishing.com/licensing/reprints.htm Or contact us for further details: permissions@emeraldinsight.com 